\title{
Clinical oncology in resource-limited settings
}

\author{
Franco M Buonaguro', Serigne N Gueye², Henry R Wabinga ${ }^{3}$, Twalib A Ngoma ${ }^{4}$, Jan B Vermorken ${ }^{5}$ \\ and Sam M Mbulaiteye ${ }^{6^{*}}$
}

\begin{abstract}
Infectious Agents and Cancer is introducing a new section of Clinical Oncology with the main objective of stimulating debate through articles published in the section. Infectious diseases have been the major causes of morbidity and mortality in human populations, and have dominated the medical approach to clinical and public health. Successful efforts to control mortality from acute infections have paved the way for chronic, mostly indolent, infections to become major causes of morbidity. Cancer, hitherto thought to be rare in resource-limited settings, is becoming a major contributor. The changes in mortality patterns are due, in part, to diseases linked to rapid changes in lifestyle, urbanization, and pollution. These diseases include many of the non-infection associated cancers. However, there is a dearth of information about the burden, pathogenesis, and therapeutic approaches about cancer in resource-limited countries. There are also substantial other challenges, including economic, infrastructure, technology, and personnel. The Journal advocates for interactive local-global (lo-bal) efforts to generate relevant knowledge about cancer burden, pathogenesis, and therapeutic approaches using a bottom-up approach to sharpen the focus on local and global relevance of research and clinical and public practice, particularly in resource-limited countries. The section on Clinical Oncology in Infectious Agents and Cancer will harness these "Io-bal" strategies to reduce substantially the time from concept, discovery, and development and implementation of locally and globally applicable diagnostic and therapeutic technologies.
\end{abstract}

\section{Editorial}

Do we really need a clinical oncology journal focusing on resource-limited countries? Many, perhaps, would be inclined to answer "no". Resource-limited countries are faced with extraordinary burdens of acute and chronic infectious agents, malnutrition, civil disturbance, violence, and economic disparity and have to make, often, painful choices how to spend their limited resources. Intuitively, those countries should focus on identifying diseases that rank top in their morbidity surveys and learning and applying strategies for early diagnosis and treatment of those conditions. Because previous morbidity surveys have indicated that acute infections, malnutrition, and maternal conditions are the leading causes of morbidity and mortality, the argument to establish and develop clinical and basic oncology services in resource-limited countries seems weak.

\footnotetext{
* Correspondence: mbulaits@mail.nih.gov

${ }^{6}$ Infections and Immunoepidemiology Branch, Div of Cancer Epidemiology and Genetics, National Cancer Institute, National Institutes of Health, Department of Health and Human Services, 9609 Medical Center Dr, Rm. 6E118 MSC 9704, Bethesda, MD 20892-9704, USA

Full list of author information is available at the end of the article
}

Yet, morbidity and mortality from cancer is substantial in many resource-limited countries. The successful efforts to control mortality from acute infections have paved the way for chronic infections to become the major causes of morbidity in resource-limited settings. Inevitably, cancer will also become important. Infectionassociated cancers already contribute to more than onethird of cancers in resource-limited settings, compared to less than one-fifth in developed countries. Concomitant increases in mortality from other diseases, which are linked to rapid changes in lifestyle, urbanization, and pollution, will undermine the gains from decreased mortality from acute infections. Clinicians working in resourcelimited countries regularly encounter patients with cancer, many patients present with late symptoms. Clinicians confront the challenges to diagnose, treat and rehabilitate patients with cancer. Public health managers confront the challenges to balance resource allocation between cancer services, for which the demand is growing steeply, and the need to meet priorities imposed by acute infections, malnutrition, and maternal disease for which the demand has historically been high. 
We lack robust data from well-designed and wellconducted studies in resource-limited settings, which complicates forecasting. Likewise, there is a dearth of information about pathogenesis, metabolic or genetic pathways and therapeutic approaches, which hampers efforts towards rational programs to mitigate the cancer burden in resource-limited countries. The challenges for developing evidence-based oncologic programs in resource-limited settings are broad and diverse.

However, there are many reasons to develop robust oncologic programs in resource-limited countries. These include humanitarian considerations: the need to provide a basic diagnosis, treatment or pain care and rehabilitation. Others include scientific considerations to estimate the burden, distribution, and trends of cancer and conduct in-depth studies of the biology of cancer. Basic science studies are necessary to develop targeted therapies. The increasing appreciation of the substantial contribution of chronic infections to cancer provides strong motivation to identify infection-associated cancers and to deploy infection control strategies to cancer control.

Infections have historically exerted tremendous evolutionary pressure on human populations. For example, pressure from malaria infections has left the glucose6-phosphate dehydrogenase (G6PD) signature mutation at nucleotide 563 (Exon 6). This mutation leads to a substitution of a phenylalanine amino acid with a serine amino acid at position 188 (SER188PHE) and it is associated with G6PD deficiency anemia and reduced risk of death from malaria [1], as initially proposed by Davidson et al., 1964 [2]. Similarly, other severe fatal infections, such as plague, smallpox HIV infection, have induced signature mutations, including the CCR5 deletion (i.e. CCR5 $\Delta 32$ ), which is associated with resistance to these diseases [3], but it might also increase susceptibility to other infections, such as the West Nile infections [4]. Other infections show peculiar distributions, but whether these disparities may be associated with signature mutations and/or specific concurrent infections or other local environmetal cofactors is unknown. For example, human herpesvirus 8 (HHV-8), the viral cause of Kaposi's sarcoma (KS), shows a peculiar gradient that mirrors KS incidence [5], but genetic factors for this disease as well as other cofactors, able to explain the different susceptibility to the infection, are largely unknown. Another important virus that shows disparity is hepatitis $\mathrm{C}$ virus $(\mathrm{HCV})$ whose prevalence in Europe is $<2.5 \%$, but is extremely high in some populations including in Southern Italy where the prevalence in people $>65$ years of age is $>30 \%$. The incidence of hepatocellular carcinoma incidence tracks imperfectly with $\mathrm{HCV}$ prevalence [6,7], but whether genetic factors or local environmental co-factors contribute is unknown. Finally, the higher incidence of colon cancer could be associated with meat consumption, as recently raised by Nobel laureate Harold zur Hausen [8]. Could the habit of eating raw meat be a factor in transmitting infections from animals to humans? The Euro-Asiatic bovines (Bos taurus) and Indian Zebu (Bos indicus) or their hybrids Bos taurus Africanus (such as Sanga or the Ugandan race AnkoleWatusi) are less susceptible to bovine infections, such as rinderpest, thus favoring them over other bovine types. Is it possible that these cows also transmit other pathogens to humans that increase the risk of cancers?

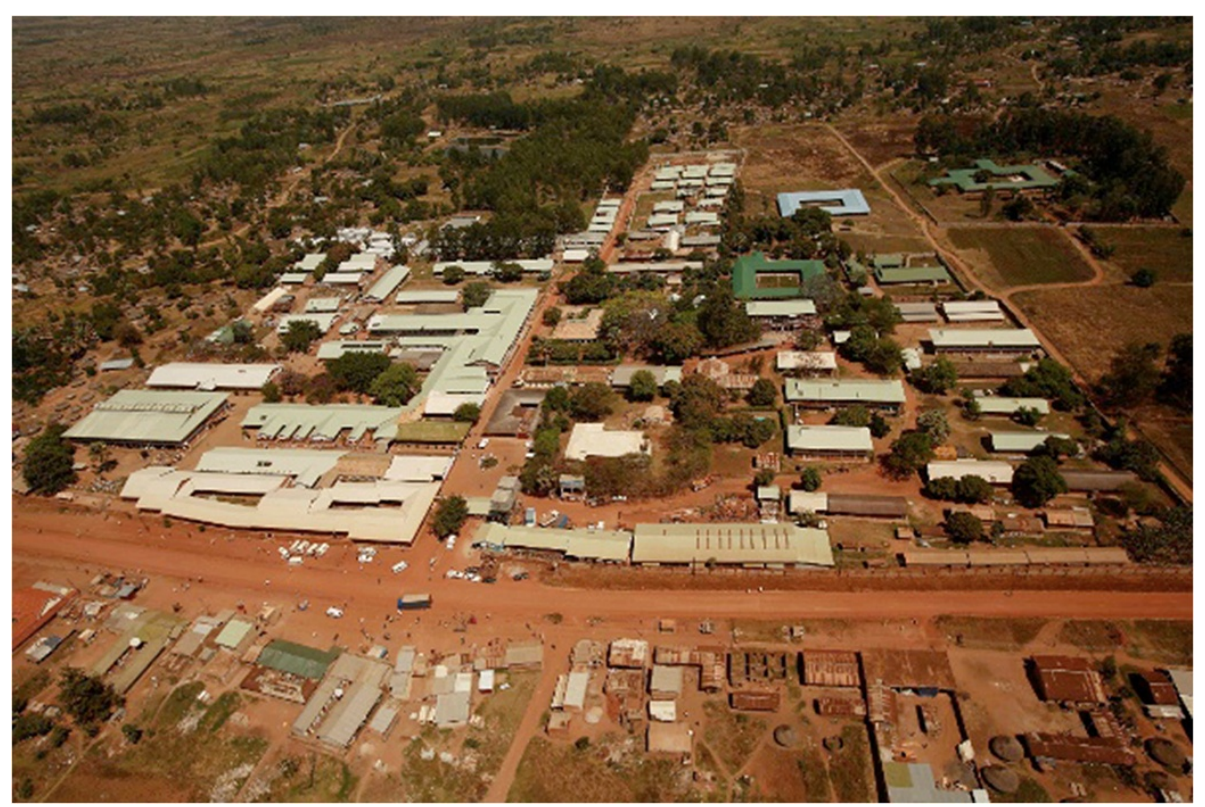

Figure 1 The St Mary's Hospital at Lacor, Gulu - Uganda. 
Studies conducted in resource-limited settings could be informative.

While serendipitous findings, such as the discovery and identification of HPV16 in cervical cancer from African patients [9] and of several HPV18 copies in HeLa cervical cancer cells [10], have driven science in the past, such opportunities arise only in the context of ongoing sustained research activity. For example, observation of extraordinarily high incidence of penile cancers in Ugandan tribes, where penile cancer represented $>40 \%$ of all male cancers was observed when research was introduced in Africa [11,12], and suggested effects of local factors. However, when civil disturbance disrupted nascent research efforts in Africa, no further scientific studies were appropriately performed and the underlying local risk factors for cancer were not identified. More recently, following the HIV epidemic, a mini-epidemic of conjunctival cancers has been reported in Africa [13], but not in the West. While the descriptive data may not lead to definitive scientific interpretation, integration of molecular data could substantially increase their relevance. Taken together, study of cancer in resource-limited settings has relevance to local communities as well as to the international community through knowledge generation [14].

For these reasons, Infectious Agents and Cancer is introducing a new section on Clinical Oncology to stimulate debate in the scientific community, along with the pharmaceutical companies, to act in concert to support nascent oncologic programs in resource-limited settings. This debate will lead to identification of the cheapest available route to a complete and effective anti-cancer regimen, for it to be pursued and implemented as for acute infectious diseases [15]. This approach will help meet the needs in limited-settings, and also bring mutual benefits to communities in wealthy countries. In a global village no one component can be left out. Wholesome clinical experience must be shared; the technological advances must be exchanged. This bottom-up approach may be referred to as the "lo-bal" strategy, where local observations are analyzed with scientific methods and the results are extrapolated for global comprehension of the phenomenon. Innovative pathogenesis studies in African populations may lead to discovery of novel genetic pathways or targets for new therapeutic approaches [16]. An integration of technological advanced oncologists with the local bio-medical community will accelerate the general scientific knowledge, while optimizing local public health programs and the general health conditions.

Young doctors from newly established Medical school lost in the bush of the dark Africa, such as at St. Mary's Hospital, Lacor, in Uganda, (Figure 1) have applied themselves to medical science. In one example, they showed that some protocols developed outside Africa, may not be easily or usefully translated to the local conditions, highlighting the need for better interaction between the more advanced scientific community and local teams $[17,18]$. The FEAST trial project, which won the BMJ Research Paper of the Year 2012 [19], is an excellent example of this. In the same hospital (Figure 1) local clinicians and nurses were able to identify and mount rapid containment, albeit at some cost of their lives, an Ebola epidemic and "produce more scientific data on Ebola". These examples indicate a thirst to learn and practice that good medicine, even extreme in terms of economic conditions and constructive interaction with the global scientific community $[20,21]$.

The "lo-bal" strategy is well developed for acute infectious diseases. It will definitely foster the sharing of experiences and information between worldwide oncologist as well as the identification and development of diagnostic and therapeutic protocols globally valid in the current global village. Infectious Agents and Cancer hopes to stimulate and contribute to this debate through articles published in the section of Clinical Oncology.

\section{Acknowledgements}

The Editorial reflects the views of the Editors-in-Chief and the section Editors, on behalf of Infectious Agents and Cancer. The content is the responsibility of the authors alone and does not necessarily reflect the views of their respective employers as well as of the publisher.

\section{Author details}

'Division of Molecular Biology \& Viral Oncology, Department of Experimental Oncology, Istituto Nazionale Tumori -IRCCS "Fond Pascale", Naples, Italy. ${ }^{2}$ Division of Urology and Andrology, Grand Yoff General Hospital -

Department of Surgery/Urology, University Cheikh Anta DIOP, Dakar, Senegal. ${ }^{3}$ Department of Pathology, College of Health Sciences, Makerere University, Kampala, Uganda. ${ }^{4}$ Ocean Road Cancer Institute, Dar es Salaam, Tanzania. ${ }^{5}$ Department of Medical Oncology, Antwerp University Hospital, Antwerp, Belgium. IInfections and Immunoepidemiology Branch, Div of Cancer Epidemiology and Genetics, National Cancer Institute, National Institutes of Health, Department of Health and Human Services, 9609 Medical Center Dr, Rm. 6E118 MSC 9704, Bethesda, MD 20892-9704, USA.

Received: 21 September 2013 Accepted: 1 October 2013

Published: 7 October 2013

\section{References}

1. Kumar V, Abbas AK, Fausto N, Aster JC: Robbins and Cotran Pathologic Basis of Disease. Expert Consult. Elsevier Health. Kindle Edition: Professional Edition; 2009.

2. Davidson RG, Childs B, Siniscalco M: Genetic variations in the quantitative control of erythrocyte glucose-6-phosphate dehydrogenase activity. Ann Hum Genet 1964, 28:61-70.

3. Galvani AP, Slatkin M: Evaluating plague and [[smallpox]] as historical selective pressures for the CCR5-Delta 32 HIV-resistance allele. Proc Natl Acad Sci USA 2003, 100:15276-9.

4. Glass WG, McDermott DH, Lim JK, Lekhong S, Yu SF, Frank WA, Pape J, Cheshier RC, Murphy PM: CCR5 deficiency increases risk of symptomatic West Nile virus infection. J Exp Med 2006, 203:35-40.

5. Buonaguro FM, Tomesello ML, Buonaguro L, Satriano RA, Ruocco E, Castello G, Ruocco V: Kaposi's sarcoma: aetiopathogenesis, histology and clinical features. J Eur Acad Dermatol Venereol 2003, 17:138-54.

6. Maio G, D'Argenio P, Stroffolini T, Bozza A, Sacco L, Tosti ME, Intorcia M, Fossi E, D'Alessio G, Kondili LA, Rapicetta M, Mele A: Hepatitis C virus infection and alanine transaminase levels in the general population: a survey in a southern Italian town. J Hepatol 2000, 33:116-120. 
7. Fusco M, Girardi E, Piselli P, Palombino R, Polesel J, Maione C, Scognamiglio P, Pisanti FA, Solmone M, Di Cicco P, Ippolito G, Franceschi S, Serraino D: Epidemiology of viral hepatitis infections in an area of southern Italy with high incidence rates of liver cancer. Eur J Cancer 2008, 44:847-53.

8. Zur Hausen H: Red meat consumption and cancer: reasons to suspect involvement of bovine infectious factors in colorectal cancer. Int I Cancer 2012, 130:2475-2483.

9. Dürst $\mathrm{M}$, Gissmann L, lkenberg H, Zur Hausen H: A papillomavirus DNA from a cervical carcinoma and its prevalence in cancer biopsy samples from different geographic regions. Proc Natl Acad Sci USA 1983, 80:3812-3815.

10. Macville M, Schröck E, Padilla-Nash H, Keck C, Ghadimi BM, Zimonjic D, Popescu N, Ried T: Comprehensive and definitive molecular cytogenetic characterization of HeLa cells by spectral karyotyping. Cancer Res 1999, 59:141-50.

11. Dodge OG, Owor O, Templeton AC: In Tumours in a tropical country. Edited by Templeton AC. Berlin: Springer; 1973:132-144.

12. Tornesello ML, Buonaguro FM, Beth-Giraldo E, Kyalwazi SK, Giraldo G Human papillomavirus (HPV) DNA in penile carcinomas and in two cell lines from high-incidence areas for genital cancers in Africa. Int I Cancer 1992, 51:587-92.

13. Wabinga HR, Parkin DM, Wabwire-Mangen F, Nambooze S: Trends in cancer incidence in Kyadondo County, Uganda, 1960-1997. Br J Cancer 2000, 82:1585-1592.

14. Levine AS: The epidemic of acquired immune dysfunction in homosexual men and its sequelae-opportunistic infections, Kaposi's sarcoma, and other malignancies: an update and interpretation. Cancer Treat Rep 1982, 66:1391-5.

15. Waning B, Diedrichsen E, Moon S: A lifeline to treatment: the role of Indian generic manufacturers in supplying antiretroviral medicines to developing countries. J Int AIDS Soc 2010, 13:35.

16. Mbulaiteye S: Burkitt Lymphoma: beyond discoveries. IAC 2013, 8:35.

17. Wanyama R: Malnutrition and child morbidity and mortality. Gulu University Medical Journal 2010, 5:11-12. http://www.kampala.cooperazione. esteri.it/utkampala/Download/GUMJ2010Final.pdf.

18. Maitland K, Kiguli S, Opoka RO, Engoru C, Olupot-Olupot P, Akech SO, Nyeko R, Mtove G, Reyburn H, Lang T, Brent B, Evans JA, Tibenderana JK, Crawley J, Russell EC, Levin M, Babiker AG, Gibb DM: FEAST trial group mortality after fluid bolus in African children with severe infection. N Engl J Med 2011, 364:2483-95.

19. The FEAST trial BMJ Research Paper award. http://www.ctu.mrc.ac.uk/ news_and_press_releases/news_archive/feast_bmj_award_24052012.aspx.

20. Harden B, Dr. Matthew's Passion: The New York Magazine, February 18, 2001 2001. http://www.nytimes.com/library/magazine/home/20010218mag-ebola. html.

21. Dimbley J: On the Ebola frontline: the story of the doctors and nurses at St Mary's Hospital, Lacor. BBC Radio Science May 26 2002. http://www.bbc.co.uk/ radio4/science/ebola.shtml.

doi:10.1186/1750-9378-8-39

Cite this article as: Buonaguro et al: Clinical oncology in resourcelimited settings. Infectious Agents and Cancer 2013 8:39.

\section{Submit your next manuscript to BioMed Central and take full advantage of:}

- Convenient online submission

- Thorough peer review

- No space constraints or color figure charges

- Immediate publication on acceptance

- Inclusion in PubMed, CAS, Scopus and Google Scholar

- Research which is freely available for redistribution

Submit your manuscript at www.biomedcentral.com/submit
Biomed Central 